\title{
Correlation Between the Crude Extracellular Secretion by Shigella dysenteriae and Destruction of RD and L20B Cell Lines, A Simple Sign as Alternative Treatments for Cancer Tumors through Cytotoxicity
}

\author{
Nagham Sh. Alattar ${ }^{1}$, Tahreer H. Saleh ${ }^{2}$ and Bahaa A.L. AL-Rubai ${ }^{*}$ \\ ${ }^{1,3}$ University of Baghdad, College of Science, Department of Biology, Baghdad, Iraq. ${ }^{2}$ Mustansiryia University, \\ College of Science, Department of Biology, Baghdad, Iraq.
}

\begin{abstract}
The clinical pathogenic strains of $S$. dysenteriae in this study were initially diagnosed as enteroinvasive $E$. coli due to the high similarity in characterization and pathogenic mechanism. The clinical samples were collected previously from patients of diarrheic stool. Confirmation was done by API 20 NE and API 20 E systems in central public health laboratory in Baghdad. The three clinical strains of $S$. dysenteriae had shown weakness in their ability to produce serine protease autotransporters (Sat), showing small clear zone (about 1-1.4 mm in diameter) around the colonies. No clear hemolysis pattern on blood agar was shown but, the lysis of human Erythrocytes was observed by hemagglutination test in twofold dilution 1/10-1/320 for non-heated bacterial supernatant. When treated with heated supernatant however, agglutination appeared, which indicates that RBCs did not lyse. The biofilm formation was evaluated in this study by Congo red plate Method which had shown weak strength in formation. The clinical strains of $S$. dysenteriae have different antibiogram analyses; it was strong sensitive against ceftriaxone, ciprofloxacin, and co-trimoxazole; while, resistant to Tetracycline, ampicillin and chloramphenicol and finally, Nalidixic acids shown intermediate susceptibility. Both non-heated and heated (at boiling temperature for $60 \mathrm{~min}$ ) supernatants had cytotoxic effect on shape and vitality of RD and L2OB cell lines. Several changes in morphology include: size, shrinkage, segregation, rounding were noted as cytopathic effect. Cell death was shown, which caused either failure of cells in suspension to attach (to a surface to form a monolayer) or detachment of cells from established monolayers within $120 \mathrm{hr}$. compared with non- treated cells as a control. There is a poor relation between cytotoxicity effect and Sat protease and hemolysin secretion of $S$. dysenteriae. But, other heat-stable toxins may involve in infectivity of $S$. dysenteriae on human cells. Also, the destruction and damage of above mentioned cell lines by extracellular production of clinical pathogens may effect cancer cells when infected with $S$. dysenteriae and become weaker. Cytotoxicity of cancer cells may leave them vulnerable and exposed to active immune cells leading to rapid death. Although the toxins of $S$. dysenteriae are dangerous, they can be employed in treatment of cancer cells or developing anti-tumor drug through destruction of tumor mass.
\end{abstract}

Keywords: Shigella dysenteriae, RD and L20B cell lines, Sat, Cytotoxicity, heated and non-heated supernatant.

*Correspondence: Bahaa974@yahoo.com

(Received: 11 September 2018; accepted: 27 November 2018)

Citation: Nagham Sh. Alattar, Tahreer H. Saleh, and Bahaa A.L. AL-Rubai, Correlation Between the Crude Extracellular Secretion by Shigella dysenteriae and Destruction of RD and L2OB Cell Lines, A Simple Sign as Alternative Treatments for Cancer Tumors through Cytotoxicity, J Pure App/ Microbiol., 2018; 12(4):2165-2174. http://dx.doi.org/10.22207/JPAM.12.4.55

(C) The Author(s) 2018. Open Access. This article is distributed under the terms of the Creative Commons Attribution 4.0 International License which permits unrestricted use, sharing, distribution, and reproduction in any medium, provided you give appropriate credit to the original author(s) and the source, provide a link to the Creative Commons license, and indicate if changes were made. 


\section{INTRODUCTION}

The bacteria and fungi caused different Infectious diseases. World Health Organization (WHO) reports that many hundreds thousand people die daily in the world from infectious diseases (Usha et al., 2010). Shigella spp. are pathogenic to humans; it is characterized as fastidious gram-negative, non-spore forming, facultative anaerobic, rod-shaped, non-motile, non-capsulated and non-lactose fermentor (Penatti et al., 2007). Warren and his co-worker reported the most common route of infection by Shigella is transmission from person-to-person by the faecal-oral route, as this microbe can survive gastric acidity better than other enteric microorganisms (Warren et al., 2006). However, transmission associated with the consumption of contaminated water, food, food handlers, contaminated swimming pools, overcrowded communities, and flies also has been documented (Ashkenazi, 2004). The bacillary dysentery or called shigellosis that caused by Shigella that has the lowest infective dose ranging from 100 to 1000 cell to cause the infection (Chang et al., 2012). The mortality and morbidity due to shigellosis were increased among young children under the age of five, elders and immuno-compromised individuals (Penatti et al., 2007; Singh et al., 2011). Recently, Shigella was ranked in the top four bacterial pathogens that cause moderate-to-severe diarrhea (Mani et al., 2016).The genus of Shigella was classified into S. flexneri, S. dysenteriae, $S$. sonnei and S. boydii (Niyogi, 2005). The virulent Shigella strains cause disease after producing several virulence factors by both chromosomal and plasmid-coded genes and invading the intestinal mucosa; but, rarely penetrates beyond the mucosa (Yang et al.,2005).The virulent strains cause cytotoxicity after synthesizing a polypeptide from responsible gene that encoded on large $(220 \mathrm{~kb})$ plasmid, the loss or disruption of this plasmid mean the loss of the ability Shigella to cause infection. Moreover, E coli 0157:H7 clinically behave as Shigella because it resort this plasmid (Friedrich et al.,2002). In many parts of the world, the incidence cases of shigellosis has increased because of emergence Multi-drug resistance Shigella spp. Early diagnosis of shigellosis would minimize the risk that caused by Shigella spp. (Khalil et al., 1998). The agitation for the bloody diarrhea is caused by lipopolysaccharide (LPS) and Shiga Toxin (an A-B toxin), which acts as a cytotoxin produced by this microbe. There are two groups coded on the chromosome that are considered as non-cross reactive, Stx 1 and Stx2. This toxin can also act as a neurotoxin and an enterotoxin (Richardson et al., 1992). LPS antigens in cell wall encoded by chromosomal genes, it plays a remarkable role in reluctance to non-specific lines of host defense which faced throughout tissue infestation. These responsible genes support the invasion, multiplication, and resistance to phagocytosis by tissue macrophages. Some article mentioned that LPS boost the cytotoxicity of Stx on some human cells such as vascular endothelial cells. On the another hand, S. flexneri strains also resort responsible gene for other virulence factor, its production of bacteriocin on large plasmid has been described. The production of the bacteriocin that encoded by genes on chromosomes may be related to dysenteric diarrhea (Schuller, 2011). This study's aim was to investigate the correlation of crude extracellular secretion from pathogenic strain of $S$. dysenteriae that may include toxins, protease and hemolysis factors with Cytopathic effect on mammalian cell lines LB20 cells (mouse fibroblast cells) and rhabdomyosarcoma-RD (common tumors cells of soft-tissue sarcomas in skeletal muscle of childhood), which may help find an alternative therapeutic approach to treat tumor cells by cytotoxicity.

\section{MATERIALS AND METHODS \\ Bacterial isolation and identification}

Three Shigella dysenteriae isolates were obtained from the Central Public Health Laboratory in Baghdad/Iraq. In order to diagnose the pathogen ,samples cultured directly by streaking on different media include blood agar, MacConkey agar, EMB agar, S.S.agar and Hektoen agar plates after sterilized by autoclave at $121{ }^{\circ} \mathrm{C}, 15 /$ inch $^{2}$ pound for 30 minutes, then incubated in aerobic conditions overnight at $37{ }^{\circ} \mathrm{C}$. The bacterial diagnosis was based on morphology, microscopic characters, and biochemical tests. Confirmation was done by API $20 \mathrm{E}$ and API 20 NE system. The purified bacterial colonies was maintained on LB slant for 3-4 weeks and in LB broth with 20\% glycerol at $-20^{\circ} \mathrm{C}$ for long time preservation for subsequent tests. 


\section{Hemolytic activity}

The hemolytic activity of $S$. dysenteriae isolates were investigated by two methods

1- The classical Blood agar method according to Lin A. and his co-workers with some modification. A single colony of each strain was transported from LB broth onto blood agar containing $5 \%(\mathrm{v} / \mathrm{v})$ human blood. The hemolysis pattern around the colonies observed after $24 \mathrm{hrs}$. incubation at $37^{\circ} \mathrm{C}$ (Lin et al., 2012).

2- Hemagglutination test according to Duguid method (Duguid, 1959). Briefly, RBCs freshly obtained from healthy volunteer were washed 2-3 time with phosphate buffer saline (PBS) and re-suspended at concentration of $2 \%$ (vol/ vol). bacterial isolates were grown overnight in brain heart infusion broth at $37^{\circ} \mathrm{C}$, washed and suspended in PBS at a concentration of about $1 \times 10^{8} \mathrm{CFU} / \mathrm{ml}$ according to turbidity matching $0.5 \mathrm{McF}$ arland standard. Serial twofold dilutions $(1 / 10-1 / 1280)$ of the bacterial suspension (heated and non-heated) in $25 \mu \mathrm{l}$ of BPS were made in U-shape microtiter plate. The positive result of hemagglutination was determined after $60 \mathrm{~min}$ at $4^{\circ} \mathrm{C}$ with granulated appearance of RBCs.

Determination of protease production (assay)

The bacterial strains inoculated in LB broth medium and incubated at $37^{\circ} \mathrm{C}$ Overnight. The culture broth was subjected to cooling centrifugation for 20 minutes with high speed $(10,000 \mathrm{rpm})$ at $4^{\circ} \mathrm{C}$ to remove unwanted particles. The supernatant was used as crude enzyme preparation. The bacterial supernatant $(20-25 \mu \mathrm{l})$ was transferred to wells in skim milk agar plates supplemented with $10 \%$ skim milk, then incubated at $37{ }^{\circ} \mathrm{C}$ for $24-48 \mathrm{hrs}$. The positive result for protease production based on clear zones around the wells and the diameters of clearance zone was measured with millimeter (Al-Rubai, 2017).

Standardization of inoculum for Antibiotic susceptibility testing

Fresh colonies from plates of nutrient agar at $37^{\circ} \mathrm{C}$ for $24 \mathrm{~h}$ were selected and suspended in Mueller-Hinton broth and then incubated at $37^{\circ} \mathrm{C}$ for $24 \mathrm{hrs}$. to a turbidity matching $0.5 \mathrm{McF}$ arland standard $\left(10^{8} \mathrm{cfu} / \mathrm{ml}\right)$ for bacteria (McFarland, 1907). The Kirby Bauer method was employed to determine the antibiogram profiles for 7 types of antibiotics against $S$. dysenteriae isolates; the common antibiotics were used provided from Oxoid include (ciprofloxacin $5 \mu \mathrm{g}$, ampicillin $10 \mu \mathrm{g}$, co-trimoxazole $25 \mu \mathrm{g}$, tetracyclin $30 \mu \mathrm{g}$, chloramphenicol $30 \mu \mathrm{g}$, ceftriaxone $30 \mu \mathrm{g}$, and Nalidixic acid $30 \mu \mathrm{g}$ ) , the diameters of inhibition zone for each antibiotics were measured with millimeter and values were indicated as resistant and sensitive categories referring to match chart of national committee for clinical laboratory standard (CLSI, 2018).

\section{Biofilm Formation}

It was determine by Congo red plate Method, the medium consisting of Brain heart infusion broth $(37 \mathrm{gm} / \mathrm{l})$, sucrose $(5 \mathrm{gm} / \mathrm{l})$ and agar number $1(10 \mathrm{gm} / \mathrm{l})$. Congo red stain was prepared as concentrated solution and autoclaved at $121^{\circ} \mathrm{C}$ for $15 \mathrm{~min}$. Then it was added to sterilize Brain heart infusion agar supported with sucrose at $55^{\circ} \mathrm{C}$. Plates were streaked with $S$. dysenteriae isolates and incubated aerobically at $37^{\circ} \mathrm{C}$ for $24-48 \mathrm{hrs}$. The positive indicator for biofilm production is black colonies with a dry crystalline consistency (Mathur et al., 2006).

\section{Heat treatment of culture supernatant}

S. dysenteriae isolates were inoculated in ten $\mathrm{ml}$ of LB broth and allowed to grow for 18 hr. at $37^{\circ} \mathrm{C}$ in incubator; the bacterial mass was harvested by cooling centrifuge at $10.000 \mathrm{rpm}$ for $20 \mathrm{~min}$ at $4^{\circ} \mathrm{C}$, the supernatant was sterilized immediately by filtration using $0.2 \mathrm{~mm}$ pore size syringe filter unite and then treated with different temperatures 50,80 and $100^{\circ} \mathrm{C}$ respectively for 60 min, the filtrate tubes placed immediately in ice bath until cooled and then applied to monolayer of RD and L20B mammalian cell lines (Al-Rubai et al., 2011).

\section{Cytopathic effect}

The mammalian $\mathrm{L} 20 \mathrm{~B}$ and $\mathrm{RD}$ were provided from Iraqi National Polio Laboratory in the center public health laboratory of Baghdad, these cells were used to investigate the cytopathogenic effect of bacterial heated and non-heated filtrated of $S$. dysenteriae isolates. The cell lines were maintained according to (Balamurugan et al., 2006) with some modification by (Al-Rubai, 2009). briefly, the cell layers allowed to grown in tissue culture flasks with DMEM supplemented with $10 \%$ fetal bovine serum albumin and then different 
common use of antibiotics such as gentamycin $40 \mu \mathrm{g} / \mathrm{ml}$, amphotericin B $1 \mu \mathrm{g} / \mathrm{ml}$, and $0.75 \mathrm{mM}$ L-glutamine were added. The cells washed gently with PBS for 1-4 times and trypsinized the fixed cells by added $0.25 \%$ of Trypsin-EDTA solution and then incubated for $6-10$ minutes at $36{ }^{\circ} \mathrm{C}$. After trysinization the cells detached and suspended well by shacked gently and then re-suspend in 20-25 $\mathrm{ml}$ of DMEM. Finely, distributed to grown in 96- well flat bottom micro titer plate at $37{ }^{\circ} \mathrm{C}$ in $5 \%$ CO2 incubator for $72 \mathrm{hrs}$ until confluent monolayer formation, the old solution medium was exchanged with $150 \mu \mathrm{l}$ of new DMEM and then added $50 \mu \mathrm{l}$ of the heated and non-heated bacterial filtrate to each well and re-incubated in incubator for $120 \mathrm{hrs}$ with same growth condition. The microtiter plate was monitored using the inverted microscope to determine and recorded any changes in morphology of cells may be caused by cell free filtrate and compared with control.

\section{RESULTS AND DISCUSSION}

The Three clinical isolates $S$. dysenteriae were collected previously from stool samples of patients suffering from severe diarrhea. The bacterial identification was re-confirmed by API 20 NE and API 20 E systems. The report by Sethabutr and his co-workers mentioned that enteroinvasive E. coli (EIEC) is very closely related with Shigella species and has a similar pathogenic mechanism. Therefore, it is evident that many enteroinvasive E. coli could be called Shigella and vice versa, this relatedness makes the differentiation between them difficult and need serotyping for complete identification (Sethabutr et al., 1993; Grimont et al., 2007). For the above reasons, only three clinical isolates were diagnosed correctly as $S$. dysenteria, after the initial diagnosis of many stool samples which was EIEC E.coli in all the other cases. The reconfirmation and differentiation between these isolates were done in Central Public Health Laboratory in Baghdad. This result indicates that the number of infections with $S$. dysenteriae is low despite the similarity of clinical signs and symptoms with $E$. coli. The asymptomatic carrier of $\mathrm{S}$. dysenteriae is believed has an important role in sustaining the organism and in the spread of the disease within susceptible people. Our results were similar to Al-Musawi's research team results that indicated the bacterial contamination with
Shigella spp. was 3.2\% (Al-Musawi et al.,2016) on the other hand, during military operation in Iraq, Shigella spp was (20\%) isolated from US Marines stool samples in 14 different battalion (Thornton et al., 2005). The survey research in both Bangladesh and Nigeria showed that the carrier rate of Shigella spp in children was 2-3\% (Ghosh et al., 2014). However, reports from different Asian countries showed that incidence rates of infection raised by Shigella ranging 3 - 13\% (Dhodapkar et al., 2008). The diarrheic stool infection that caused by $S$. dysenteriae may attributed to ability of this pathogen to adhere on the intestinal surface and induce diarrhea with pain, but the mortality is low or may cause by secretion such as neurotoxin or enterotoxin from S. dysenteriae (Richardson et al., 1992). In spite of the most pathogenic bacteria can produce different proteases and have the potential to breakdown the functional and structural proteins that comprise host tissues as well as to degradation important proteins in host defense. but in our study the ability of $S$. dysentria protease production was weak and small clear zone around the colonies occured with 1-1.4 mm diameter (table 1), the protease of Shigella classified into serine protease autotransporters (Sat), it is also, produced by diarrheagenic $E$. coli, it is enumerate among a significant virulence factors in both $E$. coli and Shigella (Henderson et al., 1998) which in turn is able to stimulate autoproteolysis of the mature protein from the Sat domain at the bacterial surface (Hendrixson et al., 1997; Stathopoulos et al., 2000) also, the isolates show low hemolysis patterns on blood agar (table 1). But, the lysis of RBCs was observed in moderate intensity by hemagglutination test for non-heated bacterial supernatant in twofold dilution $1 / 10-1 / 320$, while, agglutination appeared after treating the sample with heated supernatant which indicates that RBCs did not lyse (Table 2). The biofilm formation also was weak. The weakness in results may attributed to different reasons deal with involvement of many of the virulence factors under study or other factors such as growth conditions such as strain variation, origin, incubation temperature or, media constitute.

The agglutination appeared with heated supernatant treatment may attributed to the toxin was consider heat-labile and the lyses action was stopped by high temperature. This result can be 
concluded that hemolytic factor consider among virulence factors of $S$. dysenteriae because it lyse red blood cells. Using calcium ions to forming the transmembrane pores in the lipid bilayers of erythrocytes lead to loss of vitality and finely death of cells (Beutin et al.,1994). Some authors were reported that hemolysis was occurred by formation of a $25-\AA ̊ \AA$ pore within RBCs membrane not by hemolysis enzyme action but to action some proteins of type III secretion system like IpaB and IpaC insertion into RBC membrane. Ipa protein secretion and hemolysis were kinetically coupled processes during RBC-bacterial contact (Blocker et al., 1999).

The results of antibiogram profile were appearing in Table 3. Results of many previous studies for antibiotic susceptibility testing were different; some of antibiotics were combatable and other incompatible with our result. Till now, we do not have a decent explanation for these variation results. S. dysenteriae has a variable behavior against different antibiotics. It was sensitive to ceftriaxone, ciprofloxacin and co-trimoxazole respectively; while resistant to tetracycline, chloramphenicol and ampicillin respectively, but Nalidixic acid was appeared moderate activity against $S$. dysenteriae comparatively with control E. coli ATCC 25922.

Our results are compatible with the guidelines developed by WHO periodically, it was announced ciprofloxacin is drug of choice for infection by Shigella species (WHO, 2005). According to local previous studies for antibiogram analysis by disc diffusion method, the clinical isolates of Shigella were isolated from patients whom suffering from diarrhea were resistant to Cefotaxime, Ampicillin, Streptomycin, Nalidixic acid, and Kanamycin (Suhad, 2007) whereas, Asaad K.T. and Afaf A. were noticed resistant to Rifampicin, Ampicillin, and Amoxicillin, but it appeared sensitive to Ciprofloxacin, Nalidixic acid, Neomycin and Cefotaxime (Asaad and Afaf, 2010). The antimicrobial drug profile in Switzerland European country during period 2004-2014 for $S$. dysenteriae were appeared resistance to Amoxicillin/clavulanic acid Cephalothin, Cefotaxime, Ciprofloxacin, Azithromycin, Kanamycin, Gentamicin and Nalidixic acid, but it were shown sensitive to Ampicllin, Trimethoprim, Sulfamethoxazole, Streptomycin, Tetracycline

and Chloramphenicol (Nüesch-Inderbinen et al., 2016). The antibiotic susceptibility tests clarify that $S$. dysenteriae has a wide range of resistance to many antibiotics. This may attributed to the presence of the extra outer cytoplasmic membrane which comprised of lipoproteins, lipid bilayer, lipopolysaccharides and polysaccharides. Furthermore, misuse or abuse of natural and synthetic antimicrobial agents could be part of the involvement factors of resistance to antibiotics (Mordi and Momoh, 2009). In both medical and

Table 1. Hemolysis pattern and protease production of S. dysenteriae

\begin{tabular}{lll}
\hline $\begin{array}{l}\text { Isolates } \\
\#\end{array}$ & $\begin{array}{l}\text { Hemolysis pattern } \\
\text { on blood } \\
\text { agar plates }\end{array}$ & $\begin{array}{l}\text { Protease } \\
\text { Production on } \\
\text { skim milk agar }\end{array}$ \\
\hline 1 & weak hemolysis & $\begin{array}{l}\text { weak clear zone } \\
\text { weak clear zone }\end{array}$ \\
3 & weak hemolysis & weak clear zone \\
\hline
\end{tabular}

Table 2. Hemaaglutination test for heated and non-heated supernatant of S. dysenteries

\begin{tabular}{lll}
\hline Dilution & $\begin{array}{l}\text { Heated } \\
\text { supernatant }\end{array}$ & $\begin{array}{l}\text { Non-heated } \\
\text { supernatant }\end{array}$ \\
\hline $1 / 10$ & No-lyses & Moderate \\
$1 / 20$ & No-lyses & Moderate \\
$1 / 40$ & No-lyses & Moderate \\
$1 / 80$ & No-lyses & Moderate \\
$1 / 160$ & No-lyses & Moderate \\
$1 / 320$ & No-lyses & Moderate \\
$1 / 640$ & No-lyses & Weak \\
$1 / 1280$ & No-lyses & Weak \\
\hline
\end{tabular}

Table 3. The antibiotics susceptibility for S. dysenteriae

\begin{tabular}{lccc}
\hline $\begin{array}{l}\text { Antibiotics } \\
\text { Disk }\end{array}$ & $\begin{array}{c}\text { Disc } \\
\text { conc. } \\
(\mu \mathrm{g})\end{array}$ & $\begin{array}{c}\text { Sensitivity } \\
\text { of } \mathrm{S} . \\
\text { dysenteriae } \\
\text { in }(\mathrm{mm})\end{array}$ & Results \\
\hline Nalidixic acid & $30 \mu \mathrm{g}$ & 15 & $\mathrm{I}$ \\
Tetracycline & $30 \mu \mathrm{g}$ & 1 & $\mathrm{R}$ \\
chloramphenicol & $30 \mu \mathrm{g}$ & 10 & $\mathrm{R}$ \\
ceftriaxone & $30 \mu \mathrm{g}$ & 26 & $\mathrm{~S}$ \\
co-trimoxazole & $25 \mu \mathrm{g}$ & 19 & $\mathrm{~S}$ \\
Ampicillin & $10 \mu \mathrm{g}$ & 2 & $\mathrm{R}$ \\
ciprofloxacin & $5 \mu \mathrm{g}$ & 22 & $\mathrm{~S}$ \\
\hline
\end{tabular}


veterinary therapy, the source and period of microbial isolation, natural and the routine use of antibiotics may give rise to in wide prevalence of antibiotic resistance and development of antibiotic resistance genes particularly within the gram negative organisms. There are different mechanisms of antibiotic resistance include: decreased penetration of drug into the cell, efflux of antibiotics out the cell by efflux pumps, hydrolysis of antibiotics, and modification in target by mutation (Blair et al.,2015). The bla-TEM or bla-oxa genes are responsible for the development of ampicillin resistance, while resistance to chloramphenicol, streptomycin and tetracycline has mainly been attributed to the presence of catA1, strA and tetB genes respectively, but, the resistance to trimethoprim is associated with dhfrla or dhfrlllc genes (Toro et al., 2005).The first drugs used to treat Shigella infections were sulphonamides and followed by tetracycline and then by chloramphenicol. Shigella spp developed their resistance to all of these drugs and finely treatment was shifted to ampicillin and cotrimoxazole. Today, ceftriaxone, azithromycin and pivmecillinam are recommended by WHO against infection caused by fluoroquinolonesresistant Shigella species (Taneja and Mewara, 2016). From all above variations in susceptibility, the antimicrobial agents are of great value for bequeathing curative measures against microbial infections. Whereas, gradually development in resistance to these agents is a significant cause of attention and periodic monitoring of drug resistance of these organisms should be carried out in different geographical areas so that appropriate agent can be chosen for empiric therapy. Both mammalian RD and L20B cell lines were exposure to heat and non-heated bacterial supernatant of S. dysenteriae respectively. The oscillatory manner of the cytotoxicity analysis was appeared within $18 \mathrm{hr}$. and the $\mathrm{pH}$ value was changed within less than $24 \mathrm{hr}$. after treatment with non- heated and heated of filtrated supernatant. Cell shape was shown changes include: seizure, shrinkage, segregation, rounding was observed as cytopathic effect. Cell death completely and lyses was notes with total destruction and caused either failure of cells in suspension to attach or detachment of cells from established monolayers within $120 \mathrm{hr}$. compared with non- treated cells as a control (Fig. 1). The pathogenesis of shigellosis or bacillary dysentery involve colonization, invade the epithelial cell in the lining of the colon, causing severe inflammation, due to Shigella cells grow and multiply intracellularly and spread to neighboring epithelial cells; after that ulceration, hemorrhage and tissue demolition were occurred in last stage of shigellosis is the death of the cells that lining the colon and fibrosis of the colonic mucosa region, all these symptoms associated with abdominal pain and this sore results in the severe bloody diarrhea and may contain mucus, or pus. For this, Shigella cells may cause dysentery (Kodati et al., 2008; Hill Gaston, 2003). The abundance of extracellular secretion by Shigella spp has led to difficulty in characterizing these factors and to contravention in the enteropathogenicity. In general, cytotoxic the cell may produce severe illness in humans. These morphological changes can defined as cytopathic effects (CPE) and can be useful to classify cytotoxic, this damage may attributed together some factors such as i) Extracellular temperature - stable serine protease autotransporters (Sat) production to degrade components of extracellular matrix including collagens, laminin, elastin, and fibronectin, and finely cause the death of the cell after $120 \mathrm{hr}$. (Seshadri et al., 2006) ii) Ipa (IpaB and IpaC) protein secretion that insertion into RD and L2OB cells membrane (Schiavolin et al., 2013) and iii) Shiga Toxin (an A-B toxin). Shiga Toxin causes cell death by preventing protein synthesis by cleaving a specific adenine residue from the 28s rRNA in the 60s subunit (Richardson, 1992). These explanations are compatible with the results of cytotoxic effect on RD and L20B caused by supernatant of Aeromonas hydrophila (Al-Rubai et al., 2011).

There is no available studies refer to ability of S. dysentria to cytotoxic of RD or L20B cell lines, but there are many articles showed the cytotoxic effect of Shigella spp on other mammalian cell line. In vitro this organism has competence to infecting monolayers of Henle intestinal epithelial cells and HeLa cells line (Hale et al., 1979) S. flexneri able to invade HeLa cells with high worthiness, This critical step in the pathogenic process is encoded by a 140 megadalton plasmid which induces phagocytosis of the bacteria by host cells. The virulent plasmidassociated hemolysin is a remarkable factor in 
the invasion and amplification of Shigella spp. in different mammalian cells (Sansonetti et al., 1986). The report by Brown and his colleagues explain that Shiga toxin produced by $S$. dysenteriae leads to inhibited protein and DNA syntheses in intact HeLa cells (Brown et al., 1980). Also, Shigella is able to induce necrosis and apoptosis of host cells, the infected cells by Shigella spp or other dangerous pathogen bacteria rapidly lose membrane integrity due to the release of effector proteins such as cytoplasmic lactate dehydrogenase enzyme through the type III secretion system and the exposure of phosphatidylserine. The Interjection of a pore by Shigella spp into the infected host cell membrane result the necrosis (Nonaka et al., 2003; Hersh et al., 1999). Chen and his colleagues

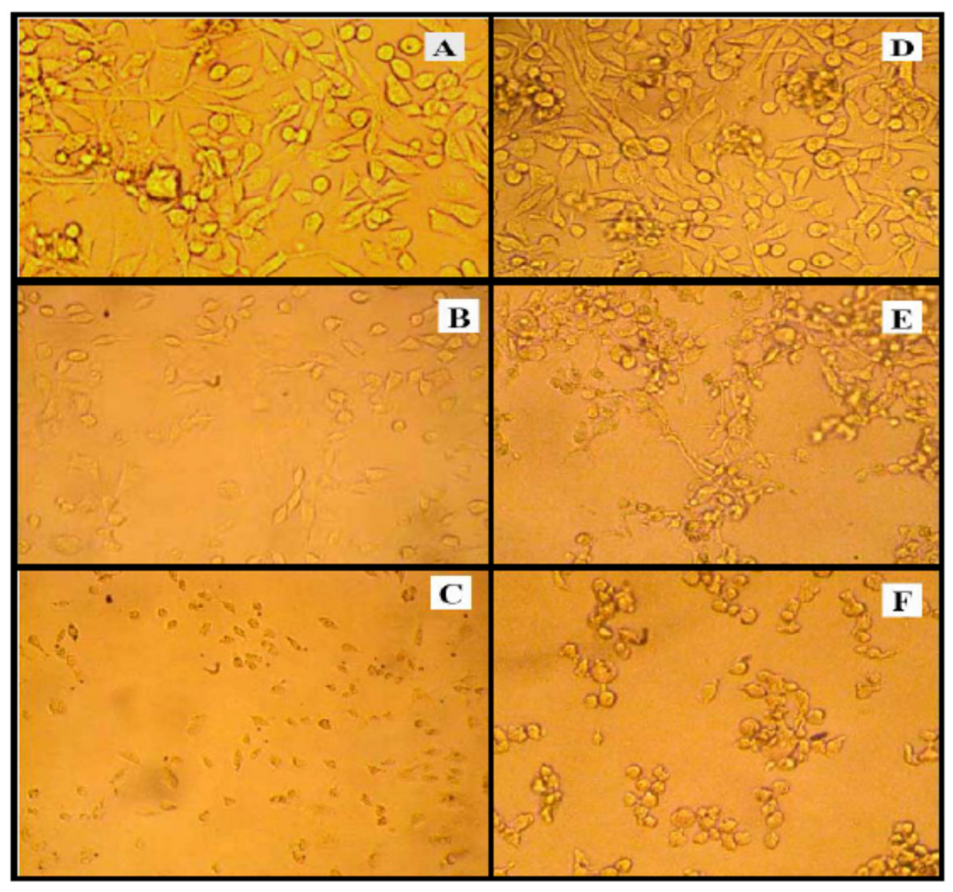

Fig. 1. The cytopathic action of $S$. dysenteries filtrate supernatant on mammalian cell lines were A: untreated RD cells B: RD cells treated with non-heated filtrate supernatant for $18 \mathrm{hr}$. the cells shown shrinking, detaching and rounded in shape $\mathbf{C}$ : degradation, lyses and most treated RD cells were death after treated with heated supernatant at $100^{\circ} \mathrm{C}$ after $120 \mathrm{hr}$. D: untreated L2OB cells E: L2OB cells shown shrinking, detaching, accumulation and rounded in shape after treated with non-heated filtrate supernatant for $18 \mathrm{hr}$ F: death most treated L20B cells with heated supernatant at $100^{\circ} \mathrm{C}$ after $120 \mathrm{hr}$.

reported that releasing IpaB by Shigella lead to kill the macrophage in infected host. This factor directly binds to and activates caspase- 1 to become as the key molecule in the induction of caspase-1-dependent apoptosis by Shigella infection (Chen et al., 1996). In the growth of the variety of virulent strain of bacteria have been appeared ability to produce spherical Nan vesicles called outer membrane vesicles (OMVs), these vesical carry many toxins such as heatlabile toxins and other virulence factors include lipopolysaccharides (LPS), DNA or RNA, lipids, and proteins (Lee et al., 2008; Kesty et al., 2004).
These vesicles contain the same above factors that are known and contain other toxin such as Shiga toxin in OMVs of E. coli O157:H7 (Kolling .and Matthews, 1999), the cytolethal distending toxin in Campylobacter jejun vesicles (Lindmark et al., 2009) and the Cif protein in OMVs of Pseudomonas aeruginosa (Bomberger et al.,2009). In our study can conclude that the haemolytic pattern by IpaB and IpaC and Sat activity of the $S$. dysenteriae might play an important role in the pathogenesis of the organism in vivo thus occurrence of the cytotoxicity. Although, the results appeared some correlation 
between Sat activity and hemolysis with cytotoxic effects, may found other extracellular factors should be highlighted in relation to pathogenicity of $S$. dysenteriae. These factors might have diverse expression or under the same genetic control. It is not improbable that different virulence factors are serious under different event. These results clarify the presence of wide spread, multiple antibiotic resistant and cytotoxic $S$. dysenteriae. The linked between the hemolysis; proteolysis and cytotoxic activities must be further estimated to genetic control of other virulence factors, mechanisms genetically and network of these virulence factors in showed the pathogenesis of S. dysenteriae. ii) The destruction and damage of Both RD and L2OB cell lines in our results by extracellular secretion produced by $S$. dysenteriae may effect on cancer cells and become weaker, the cytotoxicity of cancer cells are left alone vulnerable to attack by the active immune system and destroyed rapidly. Although the toxins of S. dysenteriae are dangerous, they can be employed to treat cancer cells as an alternative therapy or in the development of anti-tumor drugs through destruction of tumor mass.

\section{ACKNOWLEDGEMENTS}

We would like to express our gratitude to Lecturer "Mustafa A. Ali" for his linguistic help writing this paper.

\section{CONFLICT OF INTEREST}

On behalf of all authors, the corresponding author declares that there is no conflict of interest.

\section{REFERENCES}

1. Al-Musawi, M. L., Siham, B. H., Marwa, J. G., Noor Alhuda, S. H., Baraa, Z. A. Bacterial contamination of imported poultry feed in Iraq. Pharm Biol Eval, 2016; 3 (5):495-499.

2. Al-Rubai, B.A.L. Cloning LasB gene of Pseudomonas aeruginosa elastase 10104-2A1 in E. coli BL21 and E. coli DH5' and investigated their effect on the stripping of Vero cells. Pak J Biotechnol, 2017; 14 (4): 697-705.

3. Al-Rubai, B.A.L. Role of Proteus mirabilis Metalloprotease in degradation of different animal proteins and cloning of responsible gene in E.coli BL21. pH.D thesis. Biology Department. Collage of Science .Baghdad University. IRAQ, 2009.
4. Al-Rubai, B.A.L., AL-Segar, R. Q. and Malik, S. N. Detection of cytotoxic activity of clinical isolates of Aeromonas hydrophila on RD and L20B cell. Al-Mustansiriyah J Sci ,2011; 22 (4) : 65-79.

5. Asaad, K.T. and Afaf, A. Y. Effect of some antibiotic on some species of salmonella and shigella isolated from diaarhea cases. JUAPS, 2010; 4 (1), 44-50.

6. Ashkenazi, S. Shigella infections in children: new insights. Seminars in Pediatric Infectious Diseases, 2004; 15 (4): 246- 252.

7. Balamurugan, V., Sen, A., Saravanan, P., Rasool, T.J., Yadav, M.P., Bandyopadhyay, S.K. and R.K. Singh, Development and characterization of a stable Vero cell line constitutively expressing Peste des petits ruminants virus (PPRV) hemagglutinin protein and its potential use as antigen in enzyme-linked immuno-sor-bent assay for serosurveillance of PPRV. Clin Vaccine Immunol, 2006; 13(12): 1367-1372.

8- Beutin, L., Alexksic, S., Zimmerman, S. and Gleier, K. Virulence factors and phenotypical traits of verotoxigenic strains of Escherichia coli isolated from human patients in Germany. Med Microbiol Immunol, 1994; 183(1):13-21.

9. Blair, J.M.A., Webber, M.A., Baylay, A.J., Ogbolu, D.O., and Piddock, L.J.V. Molecular mechanisms of antibiotic resistance. Nat Rev Microbiol, 2015; 13: 42-51.

10. Blocker, A., Gounon, P., Larquet, E., Niebuhr, K., Cabiaux, V., Parsot, C., and Sansonetti, P. The Tripartite Type III Secreton of Shigella flexnerilnserts Ipab and Ipac into Host Membranes. J Cell Biol, 1999; 147(3), 683-693.

11. Bomberger, J.M., Maceachran, D.P, Coutermarsh, B.A, Ye, S., O.'Toole, G.A., et al. Long-distance delivery of bacterial virulence factors by Pseudomonas aeruginosa outer membrane vesicles. PLOS Pathog, 2009; 5 (4): e1000382.

12. Brown, J. E., Rothman, S. W., and Doctor, B. P. Inhibition of protein synthesis in intact HeLa cells by Shigella dysenteriae 1 toxin. Infect Immun, 1980; 29 (1), 98-107.

13. Chang, Z., Lu, S., Chen, L., Jin, Q. and Yang, J. Causative species and serotypes of shigellosis in Mainland China. systematic review and metaanalysis. PLOS ONE, 2012; 7(12): e52515.

14. Chen, Y., Smith, M. R., Thirumalai, K. and Zychlinsky, A. A bacterial invasin induces macrophage apoptosis by binding directly to ICE. EMBO J, 1996; 15 (15): 3853-3860.

15. Clinical and Laboratory Standards Institute (CLSI). Performance Standards for Antimicrobial Susceptibility Testing. 28th edition. USA: CLSI, 2018. 
16. Dhodapkar, R., Acharya, N.S., Harish, B.N. and Parija, S.C. Shigellosis in Puducherry. Indian J Med Res, 2008; 127 (6), 621-622.

17. Duguid, J. P. 1959.Fimbriae and adhesive properties in Klebsiella strains .J Gen Microbiol, 21(1):271-286.

18. Friedrich, A.W., Bielaszewska, M., Zhang, W.L., et al. Escherichia coli harboring Shiga toxin 2 gene variants: frequency and association with clinical symptoms. J Infect Dis, 2002; 185(1):74-84.

19. Ghosh, S., Pazhani, G.P., Niyogi, S.K., Nataro, J.P. and Ramamurthy, T. Genetic characterization of Shigella spp. isolated from diarrhoeal and asymptomatic children. J Med Microbiol, 2014; 63(7): 903-910.

20. Grimont, F., Lejay-Collin, M., Talukder, K.A. et al. Identification of a group of Shigella-like isolates as Shigella boydii 20. J Med Microbial, 2007; 56 (6), 749-754.

21. Hale, T.L., Morris, R.E., and Bonventre, P.F. Shigella infection of Henle intestinal epithelial cells: role of the host cell. Infect Immun, 1979; 24 (3):887-894.

22. Henderson, I. R., Navarro-Garcia, F. and Nataro, J. P. The great escape: structure and function of the autotransporter proteins. Trends Microbiol, 1998; 6 (9):370-378.

23. Hendrixson, D. R., de la Morena,M. L., Stathopoulos,C., and St Geme 3rd, J. W. Structural determinants of processing and secretion of the Haemophilus influenzae hap protein. Mol Microbiol, 1997; 26 (3):505-518.

24. Hersh, D., Monack, D. M., Smith, M. R., Ghori, N., Falkow, S. and Zychlinsky, A. The Salmonella invasin SipB induces macrophage apoptosis by binding to caspase-1. Proc Natl Acad Sci U S A, 1999; 96 (5): 2396-2401.

25. Hill Gaston, J. Arthritis associated with enteric infection. Best Pract Res Clin Rheumatol , 2003; 17 (2): 219-39.

26. Kesty,N.C., Mason, K.M., Reedy, M., Miller, S. E. and Kuehn, M.J. Enterotoxigenic Escherichia coli vesicles target toxin delivery into mammalian cells. EMBO J, 2004; 23(23): 4538-4549.

27. Khalil, K., Khan, S.R., Mazhar, K., Kaijser, B., and Lindblom, G.B. Occurrence and susceptibility to antibiotics of Shigella species in stools of hospitalized children with bloody diarrhea in Pakistan. Am J Trop Med Hyg,1998; 58 (6): 800-803, 1998

28. Kodati, V. L., Govindan, S., Movva, S., Ponnala, S. and Hasan, Q. Role of Shigella infection in endometriosis: a novel hypothesis. Med. Hypotheses, 2008; 70 (2):239-243.

29. Kolling, G.L.and Matthews, K.R. Export of virulence genes and Shiga toxin by membrane vesicles of Escherichia coli 0157:H7. Appl Environ Microbiol, 1999; 65 (5): 1843-1848.

30. Lee, H.W., Koh, Y.M., Kim, J., Lee, J.C., Lee, Y.C., et al . Capacity of multidrug resistant clinical isolates of Acinetobacter baumannii to form biofilm and adhere to epithelial cell surfaces. Clin Microbiol Infect, 2008;14 (1): 49-54

31. Lin, A., Nguyen, L., Clotilde, L.M., Kase, J.A., Son, I., Lauzon, C.R. Isolation of Shiga toxinproducing Escherichia coli from fresh produce using STEC heart infusion washed blood agar with mitomycin C. J Food Prot,2012; 75 (11):2028 $-2030$.

32. Lindmark, B., Rompikuntal, P.K., Vaitkevicius, K., Song T., Mizunoe, Y., et al. Outer membrane vesicle-mediated release of cytolethal distending toxin (CDT) from Campylobacter jejuni. BMC. Microbiol, 2009; 9: 220.

33. Mani, S., Wierzba, T., Walker, R.I. Status of vaccine research and development for Shigella. Vaccine, 2016; 34 (26): 2887-2894.

34. Mathur, T., Singhal, S., Khan, S., Upadhyay, D.J., Fatma, T., Rattan, A. Detection of biofilm formation among the clinical isolates of Staphylococci: An evaluation of three different screening methods. Indian J Med Microbiol, 2006; 24(1):25-29.

35. McFarland, J. Nephelometer an instrument for estimating the number of bacteria in suspensions used for calculating the opsonic index and for vaccines. JAMA, 1907; 14 (1), 1176-1178.

36. Mordi, R. M. and Momoh, M.I. Incidence of Proteus species in wound infections and their sensitivity pattern in the University of Benin Teaching Hospital. Afr J Biotechnol, 2009; 8(5): 725-730.

37. Niyogi, S. K. Shigellosis. Journal of Microbiology, 2005; 43(2):133-143.

38. Nonaka, T., Kuwabara, T., Mimuro, H.,, Kuwae A., and Imajoh-Ohmi, S. Shigella-induced necrosis and apoptosis of U937 cells and $\mathrm{J774}$ macrophages. Microbiology, 2003; 149 (9): 2513-2527.

39. Nüesch-Inderbinen, M., Heini, N., Zurfluh, K., Althaus, D., Hächler, H., and Stephan, R. Shigella Antimicrobial Drug Resistance Mechanisms, 2004-2014. Emerg Infect Dis, 2016; 22(6), 1083-1085.

40. Penatti, M.P.A., Hollanda, L.M., Nakazato, G., et al. Epidemiological characterization of resistance and PCR typing of Shigella flexneri and Shigella sonnei strains isolated from bacillary dysentery cases in Southeast Brazil. Braz J Med Biol Res, 
2007; 40(2):249-258.

41. Richardson, S.E., Rotman, T.A., Jay, V., et al. Experimental verocytotoxemia in rabbits. Infect Immun, 1992; 60(10):4154-4167.

42. Richardson, S.E., Rotman, T.A., Jay, V., et al. Experimental verocytotoxemia in rabbits. Infect Immun, 1992; 60(10):4154-67.

43. Sansonetti, P. J., Ryter, A., Clerc, P., Maurelli, A. T., and Mounier, J. Multiplication of Shigella flexneri within HeLa cells: lysis of the phagocytic vacuole and plasmid-mediated contact hemolysis. Infect Immun, 1986; 51(2), 461-469.

44. Schiavolin L, Meghraoui A, Cherradi Y, Biskri L, Botteaux A, Allaoui A. Functional insights into the Shigella type III needle tip IpaD in secretion control and cell contact. Mol Microbiol, 2013;88(2), 268-282.

45. Schuller, S. Shiga toxin interaction with human intestinal epithelium. Toxins (Basel), 2011; 3(6):626-39.

46. Seshadri,R., Joseph,S. W., Chopra,A. K., Jonathan Shaw, J. S., Graf,J., Haft,D., Wu,M., Ren,Q., Rosovitz,M. J., Madupu,R., Tallon,L., Kim,M., Jin,S., Vuong, O.H., Stine, C., Ali,A., Horneman, J.A. and Heidelberg, F.J. Genome Sequence of Aeromonas hydrophila ATCC 7966T: Jack of All Trades. J Bacteriol, 2006; 188(23):8272-82.

47. Sethabutr, O., Venkatesan, M., Murphy, G.S., Eampokalap, B., Hoge, C.W., Echeverria, P., Detection of Shigellae and enteroinvasive Escherichia coli by amplification of the invasion plasmid antigen $\mathrm{H}$ DNA sequence in patients with dysentery. J Infect Dis, 1993; 167 (2), 458461.

48. Singh, K. K. B., Ojha, S. C., Deris, Z. Z., and Rahman, R. A. A 9-year study of shigellosis in Northeast Malaysia: antimicrobial susceptibility and shifting species dominance. J public health, 2011; 19 (3):231-236.

49. Stathopoulos, C., Hendrixson, D. R., Thanassi, D.
G., Hultgren,S. J., St Geme 3rd, J. W., and Curtiss $3^{\text {rd }}, R$. Secretion of virulence determinants by the general secretory pathway in gram-negative pathogens: an evolving story. Microbes Infect, 2000; 2 (9):1061-1072.

50. Suhad, N. K. Study the role of salicylic acid in curing of resistance plasmids in two species of shigella) .IJ B, 2007; 6 (1), 31-41.

51. Taneja, N. and Mewara, A. Shigellosis epidemiology in India. Indian J Med Res, 2016; 143(5): 565-576

52. Thornton,S. A. , Sherman,S.S., Farkas,T., Zhong,W., Torres,P. and Jiang, X. Gastroenteritis in US Marines during Operation Iraqi Freedom. Clin Infect Dis, 2005; 40(4):519-25.

53. Toro, C.S., Farfan, M., Contreras, I., Flores, O., Navarro, N., Mora, G.C., Prado, V. Genetic analysis of antibiotic resistance determinants in multidrug-resistant Shigella strains isolated from Chilean children. Epidemiol Infect, 2005;133 (1):81-86.

54. Usha, P.T.A., Jose, S., Nisha, A.R. Antimicrobial drug resistance - a global concern. Veterinary World, 2010; 3(1):138-139.

55. Warren, B. R., Parish, M. E., and Schneider, K. R. Shigella as a foodborne pathogen and current methods for detection in food. Crit Rev Food Sci Nutr , 2006; 46 (7):551-567.

56. World Health Organization. Guidelines for the control of shigellosis, including epidemics due to Shigella dysenteriae type 1. Geneva: WHO Document Production Services; 2005. p. 1-14

57. Yang, F.; Yang, J.; Zhang, X.; Chen, L.; Jiang, Y.; Yan, Y.; Tang, X.; Wang, J.; Xiong, Z.; Dong, J.; Xue, Y.; Zhu, Y.; Xu, X.; Sun, L.; Chen, S.; Nie, H.; Peng, J.; Xu, J.; Wang, Y.; Yuan, Z.; Wen, Y.; Yao, Z.; Shen, Y.; Qiang, B.; Hou, Y.; Yu, J.; Jin, Q. Genome dynamics and diversity of Shigella species, the etiologic agents of bacillary dysentery. Nucleic Acids Res, 2005; 33 (19): 6445-58. 